\title{
Pengaruh Pupuk Silika Terhadap Pertumbuhan dan Produksi Kedelai pada Tanah Salin
}

\section{Effect of Silica Fertilizer on the Growth and Production of Soybean in Saline Soil}

\author{
Febryan Taufiq, Budi Adi Kristanto*, Florentina Kusmiyati \\ Department of Agroecotechnology, Faculty of Animal and Agricultural Science, Universitas Diponegoro, Semarang, Indonesia \\ *Corresponding author: budiadikrist@yahoo.com
}

Received: July 29, 2019; Accepted: September 15, 2020; Published: October 1, 2020

\begin{abstract}
Silica fertilizer is applied to the soil for the purpose of reducing the effects of salinity stress. This research study was conducted to examine the effect of fertilization ratio with different sources of silica to soybean growth and production on saline soil. The methods used was Completely Randomized Factorial Designs $2 \times 6$ with 3 replications. The first factor was soil salinity levels $(A)$, consists of $A 1( \pm 3 \mathrm{dS} / \mathrm{m})$ and $A 2( \pm 6 \mathrm{dS} / \mathrm{m})$. The second factor was different silica fertilizer aplications (B) which consists of B0 (without silica), B1 (100\% zeolite), B2 (75\% zeolite, $25 \%$ liquid silica), B3 (50\% zeolite, $50 \%$ liquid silica), B4 (25\% zeolite, $75 \%$ liquid silica), and B5 (100\% liquid silica). Parameters observed in this research were plant height, number of leaves, number of pods, pod weight, number of seed and seed weight. Data was analyzed by analysis of variance followed by Duncan's Multiple Range Test. The result showed that the application of silica fertilizer through soil and leaves (50\% zeolite, $50 \%$ liquid silica) improved the growth and yield of soybean on soil with moderately saline $(3 \mathrm{dS} / \mathrm{m})$. application of silica fertilizer (50\% zeolite, $50 \%$ liquid silica) improved the growth and yield of soybean. The higher soil salinity reduced soybean growth and yield. Moreover, the utilization of silica minimized the decrease in soybean growth and yield.
\end{abstract}

Key words : height, pod, weight, seed

Cite this as: Taufiq, F., Kristanto, B. A., \& Kusmiyati, F. (2020). Pengaruh Pupuk Silika Terhadap Pertumbuhan dan Produksi Kedelai pada Tanah Salin. Agrosains : Jurnal Penelitian Agronomi 22(2): 88-93. DOI: http://dx.doi.org/10.20961/agsjpa.v22i2.43385

\section{PENDAHULUAN}

Kedelai merupakan satu diantara komoditas tanaman pangan utama setelah padi dan jagung yang memiliki nilai ekonomis tinggi serta merupakan salah satu sumber protein. Tanaman kedelai memiliki banyak manfaat antara lain sebagai bahan pangan, pakan dan bahan industri. Hasil utama tanaman kedelai yang digunakan sebagai pangan yaitu biji kedelai dan jerami kedelai yang digunakan untuk pakan. Kedelai tumbuh dengan baik pada tanah dengan tekstur gembur, memiliki pH $6-6,8$, suhu optimal $25-27^{\circ} \mathrm{C}$, kelembaban rata - rata $65 \%$, lama penyinaran 12 jam per hari dan curah hujan $100-200 \mathrm{~mm} /$ bulan (Jayasumarta, 2014). Kedelai varietas Dega 1 merupakan kedelai hasil persilangan antara varietas Grobogan dan varietas Malabar. Kedelai varietas Dega 1 merupakan kedelai varietas unggul berumur genjah dan ukuran biji besar. Tipe tumbuh kedelai varietas Dega 1 yaitu tipe tumbuh Determinit dengan umur berbunga \pm 29 hari. Umur masak polong kedelai varietas Dega 1 yaitu \pm 71 hari (69- 73 hari). Kedelai tergolong tanaman tanaman yang peka terhadap salinitas dengan ambang batas toleransi $2-4 \mathrm{dS} / \mathrm{m}$. Oleh karena itu, perbaikan ketahanan kedelai terhadap salinitas dapat dilakukan melalui pemupukan yang bertujuan untuk meningkatkan pertumbuhan dan produksi kedelai pada kondisi cekaman salinitas.

Perluasan areal tanam kedelai pada lahan salin menjadi satu diantara banyak strategi dan upaya peningkatan produksi kedelai. Lahan salin memiliki dampak negatif yang menyebabkan terganggunya fungsi fisiologis, pertumbuhan dan produksi pada tanaman kedelai. Oleh sebab itu, petani kedelai di lahan salin sangat membutuhkan bantuan untuk mengurangi penurunan hasil akibat cekaman salinitas. Lahan salin di wilayah pesisir jawa meningkat setiap tahunnya, hal ini dikarenakan terjadinya instrusi air laut. Safitri et al. (2018) menyatakan bahwa luas lahan salin di Indonesia sekitar 440.300 ha dengan kriteria lahan agak salin 304.000 ha dan Iahan salin 140.400 ha. Kriteria lahan salin dibedakan menjadi 4 yaitu $0-2 \mathrm{dS} / \mathrm{m}$ (rendah), 2 - $4 \mathrm{dS} / \mathrm{m}$ (sedang), $4-8 \mathrm{dS} / \mathrm{m}$ (tinggi) dan $>8 \mathrm{dS} / \mathrm{m}$ (sangat tinggi) (Marwanto et al., 2009). Lahan salin ditandai dengan kandungan garam yang tinggi, terutama garam natrium dan klorida. Keberadaan ion $\mathrm{Na}^{+}$dan $\mathrm{Cl}^{-}$ yang tinggi menyebabkan peningkatan tekanan osmotik larutan tanah, sehingga tanaman kesulitan menyerap air, penyerapan ion $\mathrm{Na}^{+}$dan $\mathrm{Cl}^{-}$lebih banyak dibanding ion lainnya sehingga terjadi ketidakseimbangan elektrolit larutan dalam tubuh tanaman dan terjadi keracunan $\mathrm{Na}^{+}$ 
dan $\mathrm{Cl}^{-}$yang berdampak pada penurunan pertumbuhan dan produksi tanaman (Kristiono et al., 2018).

Salinitas tanah mempengaruhi seluruh proses pertumbuhan, fisiologis dan produksi pada kedelai. Salinitas tanah yang tinggi dapat menurunkan persentase pembentukan polong dikarenakan bunga yang dihasilkan berubah warna menjadi coklat dan rontok (Nisak dan Supriyadi, 2019). Pengaruh salinitas pada tanaman mengakibatkan tanaman mengalami penurunan pertumbuhan dan produksi. Kadar salinitas tanah yang tinggi menyebabkan terganggunya proses pengisian polong pada kedelai (Taufiq et al., 2017). Cekaman salinitas menyebabkan tanaman mengalami penuaan daun yang lebih cepat dan menurunkan hasil biji serta menurunkan berat polong per tanaman (Cabot et al., 2014). Hasil biji kedelai mengalami penurunan sebesar $20 \%$ pada salinitas tanah $4,0 \mathrm{dS} / \mathrm{m}$ dan penurunan $56 \%$ pada salinitas $6,7 \quad \mathrm{dS} / \mathrm{m}$ (Purwaningrahayu dan Taufiq, 2017).

Upaya yang dapat dilakukan untuk menurunkan pengaruh cekaman salinitas diantaranya adalah penggunaan pupuk silika. Silika berperan dalam ketahanan tanaman terhadap cekaman salinitas. Penyerapan unsur hara silika dalam bentuk asam silikat atau $\mathrm{Si}(\mathrm{OH})_{4}$ oleh tanaman mampu meningkatkan aktivitas enzim antioksidan selama cekaman. Silika pada tanaman dapat menghambat senyawa oksidatif penyebab cekaman dan meningkatkan enzim antioksidan sehingga pertumbuhan dan produksi tanaman dapat berjalan secara maksimal (Sapre dan Vakharia, 2016). Ikhsanti et al. (2018) mengemukakan bahwa silika dapat meningkatkan status air tanaman, menstimulasi peningkatan aktivitas enzim antioksidan yang dapat menurunkan konsentrasi spesies oksigen reaktif, imobilisasi racun $\mathrm{Na}^{+}$, mengurangi penyerapan $\mathrm{Na}^{+}$dan meningkatkan penukaran pengambilan $\mathrm{K}^{+}$.

Silika tersedia dalam berbagai bentuk diantaranya silika padat dan cair. Silika padat yang umum digunakan yaitu zeolit, sedangkan silika cair yang umum digunakan yaitu silika koloid. Zeolit merupakan silika padat yang berasal dari alumino silikat yang terhidrasi dengan kation-katian alkali dan alkali tanah. Penambahan zeolit pada tanah dapat memperbaiki struktur tanah, meningkatkan efisiensi pemupukan, meningkatkan KTK tanah, meningkatkan ketersediaan ion $\mathrm{Ca}, \mathrm{K}$, dan $\mathrm{P}$, menurunkan kandungan Al serta menambat mineral yang berguna bagi pertumbuhan tanaman (Gaol et al., 2014). Aplikasi zeolit meningkatkan ketersediaan dan serapan unsur $\mathrm{N}, \mathrm{P}, \mathrm{K}$ dan $\mathrm{Si}$ sehingga mampu meningkatkan hasil tanaman (Kristanto, 2016). Pemberian zeolit pada tanah dapat mempertahankan zat-zat nutrisi pada daerah perakaran yang dibutuhkan untuk pertumbuhan dan perkembangan tanaman (Usnawiyah dan Khaidir, 2013).

Silika cair dapat diperoleh dari proses reduksi menjadi ukuran yang lebih kecil dengan teknologi nano menjadi $\left(10^{-9} \mathrm{~m}\right)$. Pemupukan nano-silika 0,5 sampai 1 $\mathrm{mM}$ pada bibit kedelai mengurangi dampak stres garam (salinitas) dengan meningkatkan konsentrasi $\mathrm{K}+$, aktivitas antioksidan, senyawa non-enzimatik dan penurunan konsentrasi $\mathrm{Na}+$, peroksidasi lipid, dan produksi spesies oksigen reaktif (Farhangi dan Torabian, 2018). Kombinasi pemberian silika melalui tanah dan daun tanaman dapat meningkatkan hasil tanaman.
Aplikasi nanosilika+zeolit dengan dosis $150 \mathrm{kgSiO} / \mathrm{ha}$ mampu meningkatkan jumlah polong, jumlah bibit, bobot biji kedelai pada kondisi stress air (Astuti et al., 2018).

Tujuan dari penelitian ini adalah mengkaji pengaruh imbangan pemupukan dengan sumber silika berbeda terhadap pertumbuhan dan produksi kedelai pada tanah salin.

\section{BAHAN DAN METODE}

Penelitian telah

dilaksanakan pada Desember 2019 - Mei 2020 di Rumah Kaca di Balai Perlindungan Tanaman Pangan dan Hortikultura (BPTPH) Provinsi Jawa Tengah dan Laboratorium Fisiologi dan Pemuliaan Tanaman, Fakultas Peternakan dan Pertanian (FPP), Universitas Diponegoro, Semarang. Alat yang digunakan pada penelitian ini diantaranya adalah adalah EC (Electrical Conductivity) Meter. Bahan yang digunakan diantaranya adalah benih kedelai varietas Dega 1, tanah salin, zeolit, silika cair, pupuk kandang dan inokulum komersial.

Rancangan yang digunakan dalam penelitian ini adalah rancangan acak lengkap (RAL) pola Faktorial $2 \mathrm{x}$ 6 dengan 3 ulangan. Faktor pertama adalah tingkat salinitas tanah $(A)$ yaitu $A 1$ : tanah dengan tingkat salinitas sedang $(3 \pm 0,5 \mathrm{dS} / \mathrm{m})$ dan $\mathrm{A} 2$ : tanah dengan tingkat salinitas tinggi ( $6 \pm 0,5 \mathrm{dS} / \mathrm{m})$. Faktor kedua yaitu aplikasi pupuk silika yang berbeda (B) meliputi B0 (tanpa silika), B1 (100\% Zeolit), B2 (75\% Zeolit, 25\% silika cair), B3 (50\% Zeolit, $50 \%$ silika cair), B4 (25\% Zeolit, 75\% silika cair), B5 (100\% silika cair).

Data yang telah diperoleh di analisis data menggunakan ANOVA (Analysis of Variance) dan uji lanjut dengan uji jarak berganda Duncan (Duncan's Multiple Range Test $=D M R T$ ) pada taraf $5 \%$. Jika terdapat pengaruh nyata perlakuan terhadap parameter yang diamati.

Penelitian dilaksanakan dengan pengambilan tanah salin di lahan pertanian Desa Kedungmalang, Kecamatan Kedung, Kabupaten Jepara Tanah kemudian dianalisis untuk mengetahui kadar $\mathrm{N}$ menggunakan metode Kjeldahl, kadar $\mathrm{P}, \mathrm{K}$ dan $\mathrm{C}$ organik menggunakan metode Spektrofotometer, $\mathrm{pH}$ tanah menggunakan $\mathrm{pH}$ meter, dan kadar salinitas menggunakan tanah EC (Electrical Conductivity) meter (Balittanah, 2009). Data hasil analisis kimia tanah ditampilkan pada Tabel 1.

Tabel 1. Hasil Kimia Tanah Awal Penelitian

\begin{tabular}{lrc}
\multicolumn{1}{c}{ Karakteristik } & Nilai & Kriteria \\
\hline $\mathrm{C}-$ Organik (\%) & 1,16 & Rendah \\
$\mathrm{N}(\%)$ & 0,14 & Rendah \\
$\mathrm{P}_{2} \mathrm{O}_{5}$ tersedia (Olsen) & 49,24 & Sangat Tinggi \\
(ppm P) & 226,47 & Sangat Tinggi \\
$\mathrm{K}_{2} \mathrm{O}$-tersedia (ppm) & 3,41 & Sedang \\
Salinitas Tanah & & \\
Sedang (dS/m) Tingi & 6,36 & Tinggi \\
Salinitas Tanah Tingi & & Agak alkali \\
(dS/m) & 7,76 & pH $\mathrm{H}_{2} \mathrm{O}$ \\
\hline
\end{tabular}

Sumber: Hasil Analisis Tanah menurut Balittanah (2009)

Media tanam berupa tanah salin sebanyak $8 \mathrm{~kg}$ ditaruh di dalam polibag. Media tanam diberi pupuk kandang setara dosis 20 ton/Ha dan diinkubasi selama 2 minggu. Benih sebelum ditanam dibalur rhizoka dengan dosis 5 gram tiap $1 \mathrm{~kg}$ benih. Benih ditanam dengan kedalaman $3-5 \mathrm{~cm}$ sebanyak $3-5$ benih per 
polibag. Pemupukan berikutnya menggunakan urea, SP-36 dan $\mathrm{KCl}$ masing-masing setara dosis $75 \mathrm{~kg} / \mathrm{Ha}$ Urea, $100 \mathrm{~kg} / \mathrm{Ha}$ SP-36, dan $100 \mathrm{~kg} / \mathrm{Ha} \mathrm{KCl}$ (Taufiq et al., 2014). Aplikasi pupuk urea diberikan dua kali yaitu $1 / 3$ dosis rekomendasi diaplikasikan pada saat tanam dan 2/3 dosis rekomendasi diaplikasikan pada umur 4 MST. Aplikasi pupuk SP-36 dan KCl diberikan pada saat tanam. Aplikasi silika cair dilakukan setiap minggu sebanyak 5 kali atau 200 ml/tanaman dengan cara disemprot sesuai dengan dosis perlakuan sampai akhir fase vegetatif. Aplikasi zeolit dilakukan 2 minggu sebelum penanaman kedelai. Silika cair diaplikasikan melalui daun dan zeolit diaplikasikan melalui tanah. Perawatan kedelai dilakukan cara disiram. Pengendalian hama, penyakit dan gulma dilakukan jika diperlukan. Panen kedelai dilakukan pada umur 86 hari setelah tanam. Parameter yang diamati adalah tinggi tanaman, jumlah daun, jumlah polong, berat polong, jumlah biji dan berat biji.

\section{HASIL DAN PEMBAHASAN} Tinggi Tanaman Kedelai

Hasil analisis ragam menunjukkan bahwa terdapat interaksi antara perlakuan tingkat salinitas tanah dan aplikasi pupuk silika yang berbeda terhadap tinggi tanaman $(p<0,05)$. Perlakuan tingkat salinitas tanah memberikan pengaruh nyata $(p<0,05)$ terhadap tinggi tanaman. Perlakuan aplikasi pupuk silika yang berbeda memberikan pengaruh nyata $(p<0,05)$ terhadap tinggi tanaman. Hasil analisis ragam disajikan pada Tabel 2.

Tabel 2. Tinggi Tanaman pada Tingkat Salinitas Tanah dan Aplikasi Pupuk Silika yang Berbeda.

\begin{tabular}{lccc}
\hline \multirow{2}{*}{ Perlakuan } & \multicolumn{2}{c}{ Tanah Salin } & \multirow{2}{*}{$\begin{array}{c}\text { Rata- } \\
\text { rata }\end{array}$} \\
\cline { 2 - 3 } & $\begin{array}{c}\text { A1 } \\
\text { (3 dS/m) }\end{array}$ & $\begin{array}{c}\text { A2 } \\
(6 \mathrm{dS} / \mathrm{m})\end{array}$ & \\
\hline B0 (Tanpa Silika) & $50,73^{\text {de }}$ & $47,87^{\mathrm{e}}$ & $51,30^{\mathrm{e}}$ \\
B1 (100\% Zeolit) & $71,00^{\mathrm{bc}}$ & $55,83^{\mathrm{de}}$ & $63,42^{\mathrm{cd}}$ \\
B2 (75\% Zeolit, 25\% & $92,87^{\mathrm{a}}$ & $59,90^{\text {cde }}$ & $76,38^{\mathrm{ab}}$ \\
Silika Cair) & & & \\
B3 (50\% Zeolit, 50\% & $104,03^{\mathrm{a}}$ & $60,50^{\text {cde }}$ & $82,27^{\mathrm{a}}$ \\
Silika Cair) & & & \\
B4 (25\% Zeolit, 75\% & $78,73^{\mathrm{b}}$ & $59,30^{\text {cde }}$ & $69,02^{\mathrm{bc}}$ \\
Silika Cair) & & & \\
B5 (100\% Silika Cair) & $62,53^{\text {cd }}$ & $51,53^{\text {de }}$ & $57,03^{\text {de }}$ \\
Rata-rata & $77,32^{\mathrm{a}}$ & $55,82^{\mathrm{b}}$ & \\
\hline
\end{tabular}

Keterangan : huruf superskrip berbeda pada matriks interaksi, kolom dan baris rata-rata menunjukkan perbedaan nyata berdasarkan uji jarak berganda Duncan $(p<0,05)$.

Aplikasi pupuk silika, baik pada tanah dengan tingkat salinitas sedang maupun tinggi meningkatkan tinggi tanaman kedelai. Berdasarkan Tabel 2. aplikasi pupuk silika pada tanah dengan tingkat salinitas sedang meningkatkan tinggi tanaman kedelai, kecuali pada silika cair $100 \%$. Namun pada tanah dengan tingkat salinitas tinggi, peningkatan tinggi tanaman kedelai tidak signifikan (Tabel 2). Aplikasi pupuk silika (50\% zeolit, $50 \%$ silika cair) dan (75\% zeolit, $25 \%$ silika cair) pada tanah dengan tingkat salinitas sedang ( $3 \mathrm{dS} / \mathrm{m}$ ) nyata menghasilkan tinggi tanaman tertinggi yaitu $104,03 \mathrm{~cm}$ dan 92,87 cm dibandingkan perlakuan lainnya. Hal ini menunjukkan bahwa aplikasi pupuk silika cair dan zeolit dapat meningkatkan pertumbuhan dan membantu ketersediaan unsur hara bagi pertumbuhan vegetatif tanaman pada tanah salin. Hal ini sesuai pernyataan Sapre dan Vakharia (2016) bahwa silika pada tanaman dapat menghambat senyawa oksidatif penyebab cekaman dan meningkatkan enzim antioksidan sehingga pertumbuhan dan produksi tanaman dapat berjalan secara maksimal. Menurut Rahayu et al. (2019) bahwa aplikasi zeolit menyebabkan penurunkan penyerapan ion $\mathrm{Na}^{+}$, meningkatkan KTK tanah dan meningkatkan efisiensi pemupukan yang berguna bagi pertumbuhan tanaman, sehingga dapat meningkatkan tinggi tanaman.

\section{Jumlah Daun Kedelai}

Hasil analisis ragam menunjukkan bahwa terdapat interaksi antara perlakuan tingkat salinitas tanah dan aplikasi pupuk silika yang berbeda terhadap jumlah daun $(p<0,05)$. Perlakuan tingkat salinitas tanah memberikan pengaruh nyata $(p<0,05)$ terhadap jumlah daun. Perlakuan aplikasi pupuk silika yang berbeda memberikan pengaruh nyata $(p<0,05)$ terhadap jumlah daun. Aplikasi pupuk silika pada tanah dengan tingkat salinitas sedang meningkatkan jumlah daun kedelai, kecuali zeolit $100 \%$, zeolit $25 \%$ - silika cair $75 \%$ dan silika cair $100 \%$. Namun pada tanah dengan tingkat salinitas tinggi peningkatan jumlah daun kedelai tidak signifikan (Tabel 3).

Tabel 3. Jumlah Daun pada Tingkat Salinitas dan Aplikasi Pupuk Silika yang Berbeda.

\begin{tabular}{|c|c|c|c|}
\hline \multirow[b]{2}{*}{ Perlakuan } & \multicolumn{2}{|c|}{ Tanah Salin } & \multirow[b]{2}{*}{$\begin{array}{l}\text { Rata- } \\
\text { rata }\end{array}$} \\
\hline & $\begin{array}{c}\mathrm{A} 1 \\
(3 \mathrm{dS} / \mathrm{m}) \\
\end{array}$ & $\begin{array}{c}\mathrm{A} 2 \\
(6 \mathrm{dS} / \mathrm{m})\end{array}$ & \\
\hline B0 (Tanpa Silika) & $7,7^{\mathrm{cd}}$ & $6,3^{d}$ & $7,0^{\circ}$ \\
\hline B1 (100\% Zeolit) & $9,7^{b c}$ & $7,3^{\mathrm{cd}}$ & $8,5^{b c}$ \\
\hline $\begin{array}{l}\text { B2 (75\% Zeolit, 25\% Silika } \\
\text { Cair) }\end{array}$ & $11,7^{\mathrm{ab}}$ & $7,7^{\mathrm{cd}}$ & $9,7^{\mathrm{ab}}$ \\
\hline $\begin{array}{l}\text { B3 (50\% Zeolit, 50\% Silika } \\
\text { Cair) }\end{array}$ & $14,0^{\mathrm{a}}$ & $8,0^{\mathrm{cd}}$ & $11,0^{2}$ \\
\hline $\begin{array}{l}\text { B4 (25\% Zeolit, } 75 \% \text { Silika } \\
\text { Cair) }\end{array}$ & $9,7^{b c}$ & $7,0^{\mathrm{cd}}$ & $8,3^{b c}$ \\
\hline B5 (100\% Silika Cair) & $7,7^{\mathrm{cd}}$ & $7,0^{\mathrm{cd}}$ & $7,3^{c}$ \\
\hline Rata-rata & $10,1^{a}$ & $7,2^{b}$ & \\
\hline
\end{tabular}

Keterangan : huruf superskrip berbeda pada matriks interaksi, kolom dan baris rata-rata menunjukkan perbedaan nyata berdasarkan uji jarak berganda Duncan $(p<0,05)$.

Aplikasi pupuk silika pada tanah dengan tingkat salinitas sedang (3 dS/m) nyata meningkatkan jumlah daun kedelai. Hasil jumlah daun tertinggi diakibatkan oleh aplikasi pupuk silika $50 \%$ zeolit, $50 \%$ silika cair yaitu 14,0 helai dibandingkan perlakuan lainnya, namun tidak berbeda nyata dengan aplikasi pupuk silika 75\% zeolit, $25 \%$ silika cair yaitu 11,7 helai. Aplikasi pupuk silika pada tanah dengan tingkat salinitas $6 \mathrm{dS} / \mathrm{m}$ tidak berpengaruh nyata terhadap jumlah daun tanaman, hal ini dikarenakan pengaruh negatif dari cekaman salinitas yang tinggi. Cekaman salinitas pada tanah dengan tingkat salinitas tinggi menyebabkan daun tanaman mengalami klorosis. Hal ini sejalan dengan penelitian Jouyban (2012) yang menyatakan bahwa akumlasi $\mathrm{Na}^{+}$ yang tinggi pada tanaman akibat cekaman salinitas menyebabkan tanaman mengalami kerusakan dengan gejala klorosis yang berlanjut dengan gejala daun menjadi kering dan gugur. 


\section{Jumlah dan Berat Polong Kedelai}

Hasil analisis ragam menunjukkan bahwa tidak terdapat interaksi antara perlakuan tingkat salinitas tanah dan aplikasi pupuk silika yang berbeda terhadap jumlah polong per tanaman dan berat polong per tanaman. Perlakuan tingkat salinitas memberikan pengaruh nyata $(p<0,05)$ terhadap jumlah dan berat polong kedelai. Aplikasi pupuk silika yang berbeda memberikan pengaruh nyata terhadap jumlah dan berat polong kedelai $(p<0,05)$. Hasil analisis ragam disajikan pada Tabel 4.

Tabel 4. Jumlah Polong Per Tanaman pada Tingkat Salinitas dan Aplikasi Pupuk Silika yang Berbeda

\begin{tabular}{|c|c|c|c|}
\hline \multirow[b]{2}{*}{ Perlakuan } & \multicolumn{2}{|c|}{ Tanah Salin } & \multirow[b]{2}{*}{ Rata-rata } \\
\hline & $\begin{array}{c}\mathrm{A} 1 \\
\text { (3 dS/m) }\end{array}$ & $\begin{array}{c}\mathrm{A} 2 \\
(6 \mathrm{dS} / \mathrm{m})\end{array}$ & \\
\hline
\end{tabular}

-----Jumlah Polong per tanaman (buah)-----

\begin{tabular}{|c|c|c|c|}
\hline B0 (Tanpa Silika) & 6,67 & 4,33 & $5,50^{c}$ \\
\hline B1 (100\% Zeolit) & 10,67 & 6,67 & $8,67^{a b}$ \\
\hline $\begin{array}{l}\text { B2 (75\% Zeolit, 25\% } \\
\text { Silika Cair) }\end{array}$ & 11,33 & 7,33 & $9,33^{a b}$ \\
\hline $\begin{array}{l}\text { B3 (50\% Zeolit, } 50 \% \\
\text { Silika Cair) }\end{array}$ & 13,00 & 7,33 & $10,17^{a}$ \\
\hline $\begin{array}{l}\text { B4 (25\% Zeolit, } 75 \% \\
\text { Silika Cair) }\end{array}$ & 9,00 & 6,67 & $7,83^{a b}$ \\
\hline B5 (100\% Silika Cair) & 8,67 & 6,00 & $7,33^{b c}$ \\
\hline $\begin{array}{l}\text { Rata-rata } \\
\qquad---- \text { Berat Polor }\end{array}$ & $\begin{array}{l}9,89^{a} \\
\text { g per tar }\end{array}$ & $\begin{array}{l}6,39^{b} \\
(g)----\end{array}$ & \\
\hline B0 (Tanpa Silika) & 2,78 & 0,62 & $1,70^{d}$ \\
\hline B1 (100\% Zeolit) & 6,76 & 2,11 & $4,44^{\mathrm{ab}}$ \\
\hline $\begin{array}{l}\text { B2 (75\% Zeolit, 25\% } \\
\text { Silika Cair) }\end{array}$ & 7,91 & 2,96 & $5,44^{a}$ \\
\hline $\begin{array}{l}\text { B3 (50\% Zeolit, 50\% } \\
\text { Silika Cair) }\end{array}$ & 8,24 & 3,31 & $5,77^{a}$ \\
\hline $\begin{array}{l}\text { B4 (25\% Zeolit, } 75 \% \\
\text { Silika Cair) }\end{array}$ & 4,52 & 2,85 & $3,68^{b}$ \\
\hline B5 (100\% Silika Cair) & 4,43 & 1,12 & $2,78^{\mathrm{c}}$ \\
\hline Rata-rata & $5,77^{a}$ & $2,16^{b}$ & \\
\hline
\end{tabular}

Keterangan : huruf superskrip berbeda kolom dan baris ratarata menunjukkan perbedaan nyata berdasarkan uji jarak berganda Duncan $(p<0,05)$.

Tanah dengan tingkat salinitas $3 \mathrm{dS} / \mathrm{m}$ dan $6 \mathrm{dS} / \mathrm{m}$ berpengaruh nyata terhadap jumlah polong. Jumlah polong pada tanah dengan tingkat salinitas sedang (3 $\mathrm{dS} / \mathrm{m}$ ) nyata lebih tinggi 9,89 buah, dibandingkan pada tanah dengan tingkat salinitas tinggi $(6 \mathrm{dS} / \mathrm{m})$ yaitu 6,39 buah. Semakin tinggi tingkat salinitas tanah maka jumlah polong yang dihasilkan semakin rendah, karena terjadi penurunan jumlah daun (Tabel 2) dan gangguan proses fotosintesis akibat tanaman keracunan. Penurunan jumlah daun berakibat pada rendahnya fotosintesis dan keracunan ion $\mathrm{Na}^{+}$dan $\mathrm{Cl}^{-}$akan mengganggu proses fotosintesis tanaman. Hal ini sesuai pendapat Yunita et al. (2018) bahwa akumulasi ion $\mathrm{Na}^{+}$yang berlebihan pada daun mengakibatkan terganggunya proses fotosintesis dan menghambat pembentukan polong. Cekaman osmotik yang tinggi menyebabkan terganggunya penyerapan air oleh tanaman yang berakibat pada kerontokan bunga. Menurut Nisak dan Supriyadi (2019) yang menyatakan bahwa salinitas tanah yang tinggi dapat menurunkan persentase pembentukan polong sebanyak $38,64 \%$ dikarenakan bunga yang dihasilkan berubah warna menjadi coklat dan rontok.
Aplikasi pupuk silika B3 (50\% zeolit, 50\% silika cair) nyata menghasilkan jumlah polong per tanaman tertinggi yaitu 10,17 buah, tetapi tidak berbeda nyata dengan aplikasi pupuk silika B2 (75\% zeolit, 25\% silika cair), aplikasi pupuk silika B1 (100\% zeolit) dan aplikasi pupuk silika B4 (25\% zeolit, 75\% silika cair) masing-masing 9,33 buah, 8,67 buah dan 7,83 buah. Jumlah polong terendah pada tanpa aplikasi pupuk silika yaitu 5,50 buah, tetapi tidak berbeda nyata dengan aplikasi pupuk silika B5 (100\% silika cair) yaitu 7,33 buah. Aplikasi pupuk silika dapat meningkatkan kandungan unsur hara $\mathrm{K}$ dengan menurunkan penyerapan ion $\mathrm{Na}^{+}$pada tanaman yang berperan dalam proses pembentukan polong kedelai. Menurut Ikhsanti et al. (2018) bahwa silika dapat meningkatkan status air tanaman, menstimulasi peningkatan aktivitas enzim antioksidan yang dapat menurunkan konsentrasi spesies oksigen reaktif (ROS), imobilisasi racun ion $\mathrm{Na}^{+}$, mengurangi penyerapan ion $\mathrm{Na}^{+}$dan meningkatkan penukaran pengambilan ion $\mathrm{K}^{+}$.

Tanah dengan tingkat salinitas $3 \mathrm{dS} / \mathrm{m}$ dan $6 \mathrm{dS} / \mathrm{m}$ berpengaruh nyata terhadap berat polong. Berat polong per tanaman pada tanah dengan tingkat salinitas sedang ( $3 \mathrm{dS} / \mathrm{m}$ ) nyata lebih tinggi yaitu $5,77 \mathrm{gram}$, dibandingkan tanah dengan tingkat salinitas tinggi $(6 \mathrm{dS} / \mathrm{m})$ yaitu 2,16 gram. Cekaman salinitas menyebabkan tanaman mengalami klorosis dan pemasakan polong menjadi tidak maksimal. Hal ini sesuai pendapat Cabot et al. (2014) yang menyatakan bahwa cekaman salinitas 4 $\mathrm{dS} / \mathrm{m}$ atau lebih menyebabkan tanaman mengalami penuaan daun yang lebih cepat dan menurunkan hasil biji serta menurunkan berat polong per tanaman.

Aplikasi pupuk silika B2 (75\% zeolit, 25\% silika cair) dan pupuk silika B3 (50\% zeolit, $50 \%$ silika) nyata menghasilkan berat polong per tanaman tertinggi yaitu 5,44 gram dan 5,77 gram dibandingkan perlakuan lainnya. Perlakuan tanpa pupuk silika nyata menghasilkan berat polong terendah yaitu 1,70 gram, dibandingkan dengan perlakuan lainnya. Silika pada tanaman dapat meningkatkan aktivitas enzim antioksidan tanaman, sehingga dapat memperbaiki metabolisme tanaman pada kondisi cekaman. Penurunan dampak cekaman salinitas maka akan menghasilkan produksi tanaman yang lebih baik. Menurut Sapre dan Vakharia (2016) menyatakan bahwa silika pada tanaman dapat menghambat senyawa oksidatif penyebab cekaman dan meningkatkan enzim antioksidan sehingga pertumbuhan dan produksi tanaman dapat berjalan secara maksimal.

\section{Jumlah dan Berat Biji}

Hasil analisis ragam menunjukkan bahwa terdapat interaksi antara perlakuan tingkat salinitas tanah dan aplikasi pupuk silika yang berbeda terhadap jumlah dan berat biji kedelai $(p<0,05)$. Perlakuan tingkat salinitas tanah memberikan pengaruh nyata $(p<0,05)$ terhadap jumlah dan berat biji kedelai. Perlakuan aplikasi pupuk silika yang berbeda memberikan pengaruh nyata $(p<$ $0,05)$ terhadap jumlah dan berat biji kedelai. Hasil analisis ragam disajikan pada Tabel 5.

Aplikasi pupuk silika berupa B1 (100\% zeolit), B2 (75\% Zeolit, 25\% Silika Cair) dan B3 (50\% Zeolit, 50\% Silika Cair), meningkatkan jumlah biji per tanaman, baik pada tanah dengan tingkat salinitas sedang dan tinggi, namun aplikasi pupuk silika B4 dan B5 peningkatan 
jumlah biji tidak signifikan. Tanah dengan tingkat salinitas sedang (3 dS/m) dengan aplikasi pupuk silika B3 $(50 \%$ zeolit, $50 \%$ silika cair) nyata lebih tinggi menghasilkan jumlah biji per tanaman paling banyak, yaitu 24,33 buah, dibandingkan dengan perlakuan lainnya, meskipun tidak berbeda dengan dengan aplikasi pupuk silika B2 (75\% zeolit, 25\% silika cair) yaitu 21,00 buah. Aplikasi pupuk silika pada tanah dengan tingkat salinitas tinggi ( $6 \mathrm{dS} / \mathrm{m}$ ) meningkatkan jumlah biji, dan memperkecil penurunan jumlah biji per tanaman apabila dibandingkan dengan tanpa aplikasi pupuk silika pada tanah dengan tingkat salinitas sedang (A1B0). Peningkatan tingkat salinitas tanah menyebabkan tanaman mengalami cekaman osmotik dan berdampak pada penurunan tinggi tanaman (Tabel 2), jumlah daun (Tabel 3), jumlah dan berat polong (Tabel 4) dan penurunan hasil biji kedelai. Hal ini sesuai pendapat Purwaningrahayu dan Taufiq (2017) yang menyatakan bahwa hasil biji kedelai mengalami penurunan sebesar $20 \%$ pada salinitas tanah $4,0 \mathrm{dS} / \mathrm{m}$ dan penurunan $56 \%$ pada salinitas $6,7 \mathrm{dS} / \mathrm{m}$.

Tabel 5. Jumlah Biji Per Tanaman dan Berat Biji Per Tanaman pada Tingkat Salinitas dan Aplikasi Pupuk Silika yang Berbeda

\begin{tabular}{|c|c|c|c|}
\hline \multirow[b]{2}{*}{ Perlakuan } & \multicolumn{2}{|c|}{ Tanah Salin } & \multirow[b]{2}{*}{ Rata-rata } \\
\hline & $\begin{array}{c}\mathrm{A} 1 \\
(3 \mathrm{dS} / \mathrm{m})\end{array}$ & $\begin{array}{c}\mathrm{A} 2 \\
(6 \mathrm{dS} / \mathrm{m})\end{array}$ & \\
\hline \multicolumn{4}{|c|}{------Jumlah Biji Per Tanaman (biji)------ } \\
\hline B0 (Tanpa Silika) & $9,00^{\text {ef }}$ & $3,00^{9}$ & $6,00^{\mathrm{e}}$ \\
\hline B1 (100\% Zeolit) & $18,00^{\mathrm{bc}}$ & $9,00^{\text {ef }}$ & $13,50^{\mathrm{bc}}$ \\
\hline $\begin{array}{l}\text { B2 (75\% Zeolit, 25\% } \\
\text { Silika Cair) }\end{array}$ & $21,00^{\mathrm{ab}}$ & $10,00^{\text {ef }}$ & $15,50^{\mathrm{ab}}$ \\
\hline $\begin{array}{l}\text { B3 (50\% Zeolit, 50\% } \\
\text { Silika Cair) }\end{array}$ & $24,33^{a}$ & $10,33^{\text {ef }}$ & $17,23^{a}$ \\
\hline $\begin{array}{l}\text { B4 (25\% Zeolit, 75\% } \\
\text { Silika Cair) }\end{array}$ & $14,33^{\mathrm{cd}}$ & $8,00^{\mathrm{fg}}$ & $11,17^{\mathrm{cd}}$ \\
\hline $\begin{array}{l}\text { B5 }(100 \% \quad \text { Silika } \\
\text { Cair })\end{array}$ & $12,33^{\text {de }}$ & $6,67^{\mathrm{fg}}$ & $9,50^{d}$ \\
\hline Rata-rata & $16,50^{a}$ & 7,83 & \\
\hline \multicolumn{4}{|c|}{------Berat Biji Per Tanaman (g)----- } \\
\hline B0 (Tanpa Silika) & $1,87^{\text {de }}$ & $0,47^{\mathrm{g}}$ & $1,17^{e}$ \\
\hline B1 (100\% Zeolit) & $3,44^{b}$ & $1,42^{\mathrm{ef}}$ & $2,43^{b}$ \\
\hline $\begin{array}{l}\text { B2 (75\% Zeolit, 25\% } \\
\text { Silika Cair) }\end{array}$ & $3,87^{\mathrm{ab}}$ & $1,66^{\mathrm{e}}$ & $2,76^{\mathrm{ab}}$ \\
\hline $\begin{array}{l}\text { B3 ( } 50 \% \text { Zeolit, 50\% } \\
\text { Silika Cair) }\end{array}$ & $4,11^{\mathrm{a}}$ & $1,76^{\text {de }}$ & $2,94^{\mathrm{a}}$ \\
\hline $\begin{array}{l}\text { B4 (25\% Zeolit, } 75 \% \\
\text { Silika Cair) }\end{array}$ & $2,73^{c}$ & $1,32^{\mathrm{ef}}$ & $2,03^{c}$ \\
\hline $\begin{array}{l}\text { B5 }(100 \% \quad \text { Silika } \\
\text { Cair })\end{array}$ & $2,26^{c d}$ & $1,01^{f}$ & $1,64^{d}$ \\
\hline Rata-rata & $3,05^{a}$ & $1,27^{b}$ & \\
\hline
\end{tabular}

Keterangan : huruf superskrip berbeda pada matriks interaksi, kolom dan baris yang sama menunjukkan perbedaan nyata berdasarkan DMRT $(p<0,05)$

Aplikasi pupuk silika pada tanah dengan tingkat salinitas sedang $3 \mathrm{dS} / \mathrm{m}$ dapat meningkatkan ketahanan tanaman kedelai pada kondisi cekaman salinitas. Hal ini sesuai pendapat Farhangi dan Torabian (2018) yang menyatakan bahwa pemupukan nano-silika 0,5 sampai $1 \mathrm{mM}$ pada bibit kedelai mengurangi dampak stres garam (salinitas) dengan meningkatkan konsentrasi $\mathrm{K}^{+}$, aktivitas antioksidan, senyawa non-enzimatik dan penurunan konsentrasi $\mathrm{Na}^{+}$, peroksidasi lipid, dan produksi spesies oksigen reaktif. Aplikasi pupuk silika pada tanah dapat meningkatkan kemampuan tanah dalam menjerap air serta unsur hara $P$ dan $K$ yang dibutuhkan dalam proses pembentukan bunga, polong dan biji pada tanaman kedelai. Santi et al. (2018) berpendapat bahwa pemberian silika pada tanah bertujuan untuk mengatasi ketersediaan air dan penyerapan unsur hara $\mathrm{P}$ dan $\mathrm{K}$ dalam tanah.

Aplikasi pupuk silika B3 (50\% zeolit, 50\% silika cair) pada tanah dengan tingkat salinitas sedang, nyata lebih tinggi meningkatkan hasil biji per tanaman yaitu 4,11 gram, dibandingkan dengan perlakuan lainnya, tetapi tidak berbeda dengan aplikasi pupuk silika B2 (75\% zeolit, $25 \%$ silika cair) yaitu 3,87gram. Namun pada tanah dengan tingkat salinitas tinggi (6 dS/m), peningkatan hasil biji tidak signifikan, tetapi mampu memperkecil penurunan hasil biji terhadap hasil biji pada tanah dengan tingkat salinitas sedang tanpa aplikasi pupuk silika (A1B0).

Aplikasi pupuk silika berupa zeolit dan silika cair pada tanah salin dapat meningkatkan ketersediaan hara dalam tanah dan efisiensi pemupukan, meningkatkan jumlah unsur yang diserap tanaman sehingga meningkatkan pertumbuhan dan perkambangan tanaman. Menurut pendapat Kristanto (2016), bahwa aplikasi zeolit meningkatkan ketersediaan dan serapan unsur N, P, K dan Si sehingga mampu meningkatkan hasil tanaman. Menurut Usnawiyah dan Khaidir (2013) bahwa aplikasi zeolit pada tanah dapat mempertahankan zat-zat nutrisi pada daerah perakaran yang dibutuhkan untuk pertumbuhan dan perkembangan tanaman. Menurut pendapat Astuti et al. (2018) yang menyatakan bahwa aplikasi nanosilika+zeolit dengan dosis $150 \mathrm{kgSiO} / \mathrm{ha}$ mampu meningkatkan jumlah polong, jumlah bibit, bobot biji kedelai pada kondisi stress air.

\section{KESIMPULAN}

Aplikasi silika berupa zeolit dan pupuk silika cair dapat meningkatkan pertumbuhan tanaman dan hasil biji kedelai pada tanah dengan tingkat salinitas sedang (3 $\mathrm{dS} / \mathrm{m})$. Aplikasi silika berupa zeolit dan pupuk silika cair pada tanah dengan tingkat salinitas tinggi mampu memperkecil penurunan hasil biji kedelai ( $6 \mathrm{dS} / \mathrm{m})$.

\section{DAFTAR PUSTAKA}

Astuti, K. Y., Kristanto, B. A., \& Kusmiyati F. (2018). Aplikasi silika dalam upaya peningkatan ketahanan tanaman dan produksi kedelai hitam (Glycine max I. merill) yang mengalami stres air. E-Prosiding Semnas BAPPEDA Provinsi Jawa Tengah, 2 (2) : 152 - 159. ISBN: 978-602-8916-35-6. http://ejournal.bappeda.jatengprov.go.id.

Balittanah. (2009). Analisis Kimia Tanah, Tanaman, Air, dan Pupuk (Petunjuk Teknis 2). Balai Penelitian Tanah, Bogor.

Cabot, C., Sibole J. V., Barcelo, J., \& Poschenrieder, C. (2014). Lesson from crops plants struggling with salinity. J. Plant Science, $226: 2-13$.

Farhangi, S., \& Torabian, A. S. (2018). Nano-silicon alters antioxidant activities of soybean seedlings under salt toxicity. J. Protoplasma, 255 (3) : $953-$ 962.

Gaol, L., Karto, S., Hanum, H., \& Sitanggang, G. (2014). Pemberian zeolit dan pupuk kalium untuk meningkatkan ketersediaan hara $\mathrm{K}$ dan pertumbuhan kedelai di Entisol. J. Agroekoteknologi Universitas Sumatera Utara, 2 (3) : 1151 - 1159. 
Ikhsanti, A., Kurniasih B., \& Indradewa, D. (2018). Pengaruh aplikasi silika terhadap pertumbuhan dan hasil tanaman padi (Oriza sativa) pada kondisi salin. J. Vegetalika, 7 (4) : 1 - 11.

Jayasumarta, D. (2015). Pengaruh sistem olah tanah dan pupuk $p$ terhadap pertumbuhan dan produksi

(Sorghum bicolor (I.) Moench) terhadap Cekaman Kekeringan dan Pemupukan Silika. Disertasi. Universitas Gadjah Mada. Program Pasca Sarjana Universitas Gadjah Mada, Yogyakarta (Tidak dipublikasikan).

Kristiono, A., Purwaningrahayu, R. D., \& Taufiq, A. (2018). Respons tanaman kedelai, kacang tanah, dan kacang hijau terhadap cekaman salinitas. J. Buletin Palawija, 26 (1) : $45-60$.

Marwanto, S., Rachman, A., Erfandi, D., \& Subiksa, I. G. M. (2009). Tingkat salinitas tanah pada lahan sawah intensif di Kabupaten Indramayu, Jawa Barat. Balai Penelitian Tanah, Bogor. 175 - 190.

Nisak, S. K., \& Supriyadi, S. (2019). Biochar sekam padi meningkatkan pertumbuhan dan hasil tanaman kedelai di tanah salin. J. Pertanian Presisi, 3 (2) : $165-176$.

Purwaningrahayu, R. D. (2018). Karakter morfofisiologi dan agronomi kedelai toleran salinitas. J. Iptek Tanaman Pangan, 11 (1) : 35 - 48.

Purwaningrahayu, R. D., \& Taufiq, A. (2017). Respon morfologi empat genotip kedelai terhadap cekaman salinitas. J. Biologi Indonesia, 13 (2) : $175-188$.

Rahayu, R., Syamsiyah, J., \& Dewi, L. (2019). Effects of Gypsum and Zeolite on Nutrient Uptake and Shallot (Allium ascalonium L.) Growth on Irrigated Saline Entisol. J. of Tropical Soils, 24 (2) : $73-81$.

Safitri, R., Fuskhah, E., \& Karno. (2018). Karakteristik fotosintesis dan produksi kedelai (Glycine max I. Merrill) akibat salinitas air penyiraman yang berbeda. J. of Agro Complex, 2 (3) : 244 - 247. tanaman kedelai (Glycine max L. Merril). AGRIUM : J. IImu Pertanian, 17 (3) : 148 - 154.

Jouyban, Z. (2012). The effects of salt stress on plant growth. Tech. J. Engin \& App Sci. 2(1): $7-10$.

Kristanto, B. A. (2016). Tanggapan Sorgum Manis

Santi, L. P., D. H. Goenadi, J. Barus, dan A. Dariah. (2018). Pengaruh bio-nano silika terhadap hasil dan efisiensi penggunaan air kedelai hitam di lahan kering masam. J. Tanah dan Iklim, 42 (1) : $43-52$.

Sapre S. S, and D. N. Vakharia. (2016). Role of silicon under water deficit stress in wheat: (Biochemical perspective): A review. Agricultural Reviews. 37 (2) : $109-116$.

Susianto, N. C., Hariyono, D., \& Aini, N. (2018). Pengaruh aplikasi gypsum dan pupuk kandang sapi pada tanah salin terhadap pertumbuhan dan hasil tanaman kedelai (Glycine max L. Merri). PLANTROPICA: J. of Agricultural Science, 1 (2) $: 55-63$.

Taufiq, A., Wijanarko, A., \& Kristiono, A. (2017). Pengaruh genotipe dan ameliorasi terhadap pertumbuhan dan hasil kedelai pada tanah salin. $J$. Buletin Palawija, 14 (1) : 1 - 8.

Taufiq, A., Yusuf, M., Adie, M. M., Saleh, N., Iswanto, R., Kasno, A., \& Subandi. (2014). Teknologi Produksi Kedelai, Kacang Tanah, Kacang Hijau, Ubi Kayu, dan Ubi Jalar. Balai Penelitian Tanaman Aneka Kacang dan Umbi, Malang.

Usnawiyah, U \& Khaidir. (2013). Respon pemberian mikoriza arbuskular dalam media zeolit terhadap pertumbuhan dan hasil tanaman kedelai. $J$. AGRIUM, 10 (1) : 1 - 4.

Yunita, S. R., Sutarno, S., \& Fuskhah, E. (2018). Respon beberapa varietas Kedelai (Glycine max L. Merr) terhadap tingkat salinitas air penyiraman. J. Agro Complex, 2 (1) : $43-51$. 